\title{
INSTRUÇÕES AOS AUTORES DE TEXTOS INSTRUCTIONS FOR THE AUTHORS
}

a) A Revista Arteriais aceitará textos em língua portuguesa, inglesa e espanhola. Todos os trabalhos deverão ser enviados por e-mail (revista.arteriais@ gmail.com) à: Editora da Revista Arteriais.

b) A Revista Arteriais não aceitará a submissão de mais de um artigo do mesmo autor e ou coautor para um mesmo número ou em números sucessivos da revista.

c) $\mathrm{O}(\mathrm{s})$ autor(es) que tiver(em) seu texto aprovado deverá(ão) enviar à Editoria da Revista uma Carta de Cessão (modelo Revista Arteriais), cedendo os direitos autorais para publicação, em formato eletrônico, em regime de exclusividade e originalidade do texto, pelo período de 2 (dois) anos, contados a partir da data de publicação do artigo na Revista.

d) Os Artigos deverão ter uma extensão entre $12 \mathrm{e}$ 24 páginas, incluindo resumo, abstract, palavraschave, texto e referências.

e) As Resenhas deverão apresentar entre quatro e seis páginas e as Entrevistas, de dez a quinze páginas.

f) Todos os trabalhos deverão ser enviados anexados ao e-mail revista.arteriais@gmail.com, em arquivo no programa Word for Windows 7.0;

g) Os textos dos Artigos, Resenhas e Entrevistas devem ser escritos em Times New Roman, fonte 12 , espaço 1.5 , margens 2,5 ;

h) A primeira página do texto dos Artigos deve conter:

TÍTULO

Resumo com cerca de 08 (oito) linhas, alinhamento à esquerda, contendo campo de estudo, objetivo, método, resultados e conclusões. O Resumo deve ser colocado logo abaixo do título e acima do texto principal.

Três (3) palavras-chaves, alinhamento justificado.

i) Em separado, deverá ser enviada uma página com o título dos Artigos, Resenhas e Entrevistas, a) ARTERIAIS Journal accepts papers in Portuguese, English and Spanish. All the papers might me sent by e-mail (revista.arteriais@gmail. com) to: Arteriais Journal Editor;

b) Arteriais Journal will not accept the submission of more than one paper from the same author and/ or co-author for the same issue or for a successive issue of the journal;

c) The author(s) with an approved paper must send to the Editor of the magazine a Grant Letter (Arteriais Journal model), assigning the publication rights, in electronic format, due to the regime of exclusivity and originality of the text for the term of 2 (two) years, which might be counted after the publication of the paper in the magazine;

d) The articles might have an extension of 12 to 24 pages, including abstract, English and Portuguese, keywords, text and references;

e) The reviews must have four to six pages and interviews must have ten to fifteen pages;

f) All the papers must be sent attached to the e-mail revista.arteriais@gmail.com, in Word for Windows 7.0 format;

g) All the Articles, Reviews and Interviews must be written in Times New Roman, font 12, space 1.5, margins 2.5;

h) The first page of the Articles must contain:

TITLE

Abstract with an average of 08 (eight) lines, aligned to the left, containing field of study, objectives, methodology, results and conclusion. The Abstract must come right after the title and before the main text.

Three (03) keywords, justified alignment

i) A separate sheet must be sent containing the title of the Article, Review and Interview, followed by the identification of the author(s) - full name, institution, function, address mail, phone and e-mail; 
seguido da identificação do(s) autor(es) - nome completo, instituição à qual está(ão) ligado(s), cargo, endereço para correspondência, fone e e-mail.

j) Incluir um Curriculum Vitae resumido com extensão máxima de 150 palavras, contendo as principais atividades na área do(s) autor(es) dos Artigos, Resenhas e Entrevistas.

k) Os textos devem ser escritos de forma clara e fluente.

l) As notas dos Artigos devem vir ao final do texto, em espaço simples, fonte tamanho 12 e alinhamento justificado.

m) Nos Artigos as citações com menos de três linhas devem ser inseridas no texto e colocadas entre aspas, seguidas da indicação da fonte pelo sistema autor-data. As citações que excederem três linhas devem ser colocadas em destaque, fonte 11 , espaço simples, entrada alinhada a $4 \mathrm{~cm}$ da margem, à esquerda, seguidas da indicação da fonte pelo sistema autor-data. No caso de citações de obras em língua estrangeira, essas devem aparecer no texto conforme o original podendo ser apresentadas as respectivas traduções para o português, em nota de rodapé, caso a língua de origem não seja espanhol ou inglês.

n) As indicações das fontes entre parêntesis, seguindo o sistema autor-data, devem ser estruturadas da seguinte forma:

Uma obra com um autor: (BARROS, 2011, p.30)

Uma obra com até três autores: (MANESCHY; SAMPAIO, 2007, p.120)

Uma obra com mais de três autores: (SARRAF et al., 2010, p.21-22)

Mesmo no caso das citações indiretas (paráfrases), a fonte deverá ser indicada, informando-se também a(s) página(s) sempre que houver referência não à obra como um todo, mas sim a uma ideia específica apresentada pelo autor.

o) Tabelas e quadros devem ser anexados ao texto, com a devida numeração (ex. Tabela 1, etc.). No corpo do texto deve ser indicado o lugar das tabelas.

p) Não serão aceitos artigos que estiverem fora das normas editoriais. O meta-artigo (template) pode ser visualizado em link da revista. A critério dos editores, poderá ser estabelecido um prazo j) Include a brief Resume with no more than 150 words, containing the main activities in the area of the author(s);

k) The texts must be written on a clear and objective way;

I) The notes of the article must come at the end of the text, space simple, font 12 and justified alignment;

m) For the Articles, the quotes with less than three lines must come along with the text between quotation marks, followed by the indication of the reference by the system author-date. The quotations that exceed three lines must be emphasized, font 11, space simple, entry aligned at $4 \mathrm{~cm}$ of the margin, to the left, followed by the indication of the reference by the system author-date. In the case of quotations from works in foreign language, they must come according the original reference and may be translated to Portuguese, in the area for the footnotes, if the original language is not Spanish or English;

n) The indications of the references between parentheses, following the system author-date, must be structured according to the following way:

One reference with one author: (BARROS, 2011, p.30)

One reference with until three authors: (MANESCHY; SAMPAIO, 2007, p.120)

One reference with more than three authors: (SARRAF et al., 2010, p.21-22)

Even in the case of indirect quotations (paraphrase), the reference must be pointed out, also informing the page(s), even if there is a reference not to the general work, but to a specific idea presented by the author;

o) Tables and charts must be attached to the text, with the proper numeration (ex. Table 1 etc.). The place of the Tables must be indicated in the text;

p) Articles that do not follow the Editorial rules will not be accepted. The meta-Article (template) might be visualized through a link on the homepage of the magazine. At the discretion of the editors, a certain period can be set so that the author(s) can make a revision of the text (corrections of references, quotations, grammar, and spelling). In this case, the failure to follow the deadline and 
determinado para que o(s) autor(es) efetue(m) uma revisão do texto (correções de referências, citações, gramática e escrita). Nesse caso, o não cumprimento do prazo e/ou a inadequação da revisão poderão implicar a não aceitação do trabalho para publicação.

\section{REFERÊNCIAS:}

Devem ser apresentadas em espaço simples, com alinhamento apenas à esquerda, seguindo as normas da ABNT abaixo exemplificadas.

\section{LIVROS}

SOBRENOME, Inicial do prenome(s) do(s) Autor(es). Título do trabalho: subtítulo [se houver]. edição [se não for a primeira]. Local de publicação: Editora, ano.

\section{PARTES DE LIVROS (CAPÍTULOS, ARTIGOS EM COLETÂNEAS, ETC.)}

SOBRENOME, Inicial do prenome(s) do(s) Autor(es) da Parte da Obra. Título da parte. In: SOBRENOME, Inicial do prenome(s) do(s) Autor(es) da Obra. Título do trabalho: subtítulo [se houver]. edição [se não for a primeira]. Local de publicação: Editora, ano. página inicial-final da parte.

\section{ARTIGOS EM PERIÓDICOS}

SOBRENOME, Inicial do prenome(s) do(s) Autor(es) do Artigo. Título do artigo. Título do Periódico, Local de publicação, número do volume, número do fascículo, página inicial-final do artigo, data

\section{TRABALHOS EM ANAIS DE EVENTOS CIENTÍFICOS}

SOBRENOME, Inicial do prenome(s) do(s) Autor(es) do Trabalho. Título do trabalho. In: NOME DO EVENTO, número do evento, ano de realização, local. Título. Local de publicação: Editora, ano de publicação. página inicial-final do trabalho.

\section{IMAGENS}

As imagens devem ser apresentadas numeradas, em arquivo (aproximado) de 21 x $26 \mathrm{~cm}$ e 300 dpi, enviadas no formato JPG. As miniaturas das imagens com: autor, título, técnica, dimensões, fonte e autoria, devem vir no corpo do texto.
I or inadequacy of the review may lead to the rejection of the paper for publication.

\section{REFERENCES:}

They must be typed simple-spaced, aligned just to the left, following the rules from $A B N T$, as it follows:

\section{BOOKS}

AUTHOR'S LAST NAME, followed by the author's first name initial. Title of the work: subtitle [just if it has]. Edition [if it is not the first]. Place of publication: Publisher, year. Initial page - last page.

CHAPTER IN BOOKS (CHAPTERS, ARTICLES IN SELECTIONS ETC.)

AUTHOR'S LAST NAME, followed by the author's first name initial. In: AUTHOR'S LAST NAME, followed by the author's first name initial from the work. Title of the work: subtitle [just if it has]. Edition [if it is not the first]. Place of publication: Publisher, year. Initial page - last page.

\section{ARTICLES IN JOURNALS}

AUTHOR'S LAST NAME, followed by the author's first name initial. Title of the Journal, Place of publication, number of the volume, number of the issue, Initial page - last page.

\section{ARTICLES FROM SCIENTIFIC EVENTS ANNALS}

AUTHOR'S LAST NAME, followed by the author's first name initial. Title of the article. In: NAME OF THE EVENT, number of the event, year of realization, place. Title. Place of publication: Publisher, year of publication. , Initial page - last page.

\section{IMAGES}

Images must be submitted numbered, in a file (approx.) of $21 \times 26 \mathrm{~cm}$ and $300 \mathrm{dpi}$, sent in JPG format. Thumbnails of images also containing the following information for each one of them: author, title, technique, dimensions, source and authorship must be inside the text. 


\title{
INSTRUÇÕES AOS AUTORES DE PARTITURAS
}

\author{
INSTRUCTIONS FOR THE AUTHORS OF SCORES
}

A composição deve ser enviada em arquivo PDF com tamanho máximo de $5 \mathrm{MB}$. A partitura deve conter os seguintes elementos, de acordo com sua utilização: título da obra, instrumentação, autor, local e data de composição, letrista (se houver), indicações de andamento, compasso, dinâmica e articulação, e numeração dos compassos e páginas. Para composições que utilizam recursos especiais ou técnicas estendidas, recomenda-se o envio da bula. No caso de obras que utilizam suportes audiovisuais, os mesmos devem ser disponibilizados na forma de arquivos: MP3 para áudio, WMA para vídeo e JPG para figura. Estes arquivos devem ter tamanho máximo de $2 \mathrm{MB}$. Pode ser disponibilizada, também, uma gravação da composição em arquivo MP3 com tamanho máximo de $3 \mathrm{MB}$. Pede-se mini currículo e um texto crítico (uma lauda) apresentando o trabalho.
The composition must be sent in PDF format with the maximum of $5 \mathrm{MB}$. The score must contain the following elements, according to its use: title of the composition, instrumentation, author, date and place of composition, lyricist (if any), tempo markings, compass, dynamics and articulation, and numbering of bars and pages. For compositions using special features or extended techniques, it is recommended to send the leaflet. For works that use audiovisual media, they should be made available in the form of files: MP3 for audio, WMA for video and JPG for figure. These files must have a maximum size of $2 \mathrm{MB}$. It may also be provided a recording of the composition in MP3 file with maximum size 3 of $M B$. It is required a mini resume and a critical text (one page) presenting the work.

\section{INSTRUÇÕES AOS AUTORES DE PORTFOLIO}

\section{INSTRUCTIONS FOR THE AUTHORS OF PORTFOLIO}

Pede-se que sejam submetidas até 10 imagens, acompanhadas de mini currículo e de um texto crítico (uma lauda) apresentando o trabalho.

As imagens devem ser apresentadas numeradas, em arquivo (aproximado) de $21 \times 26 \mathrm{~cm} \mathrm{e} 300 \mathrm{dpi}$, enviadas no formato JPG. Deve acompanhar um arquivo com documento em Word trazendo as miniaturas das imagens contendo, ainda, as seguintes informações para cada imagem: autor, título, técnica, dimensões, fonte e autoria. Caso haja dados desconhecidos, fazer uso de s.d., de acordo com a sequência de informações indicadas aqui.
It is required to be submitted up to 10 images accompanied by mini resume and a critical text (one page) presenting the work.

Images must be submitted numbered, in a file (approx.) of $21 \times 26 \mathrm{~cm}$ and $300 \mathrm{dpi}$, sent in JPG format. It is required a document in Word file with bringing the thumbnails of images also containing the following information for each one of them: author, title, technique, dimensions, source and authorship. If there is unknown data, use s.d., according to the sequence of information provided here. 


\section{CONTATO}

CONTACT

Universidade Federal do Pará

Instituto de Ciêncas da Arte

Programa de Pós-Graduação em Artes

Homepage: www.ppgartes.ufpa.br/site

Revista ARTERIAIS

Avenida Governador Magalhães Barata, n.) 611,

CEP 60060-281, Belém-Pará-Brasil

E-mail: revista.arteriais@gmail.com

Homepage: http://www.periodicos.ufpa.br/index.

php/ppgartes/index

Telefone: +55 - 91 - 3249-2905 